\title{
AN EVENT AT THE DAWN OF MODERN KOREAN POETRY: KIM SOWOL'S "AZALEAS"
}

\section{MYEONG KYO JEONG, Prof.}

\author{
Department of Korean Language and Literature, \\ College of Liberal Arts, Yonsei University, \\ 50 Yonsei-ro, Seodaemun-gu, Seoul 120-749 \\ South Korea \\ circe@yonsei.ac.kr
}

ORCID: https://orcid.org/0000-0002-2707-8444

\begin{abstract}
Kim Sowol is one of the Korean poets who opened the horizon of modern poetry in Korea. His poem, "Azaleas" (1925) has been known as a masterpiece which Korean people love most to recite, comparable to "To Cassandra" of Pierre de Ronsard in France. Nevertheless, this poem has been taken for the highest expression of the traditional sentiment without being appreciated for the quality of the modern poetry as follows: Koreans have sung for a long time the sorrow that arises from parting with the lover. In "Azaleas", any reader can see easily the repetition of the same situation and same feeling. In this article I analyzed the attitude and the intention of the speaker of this poem and reinterpreted the theme of poem. In doing so, I found the clever strategy of the speaker in front of the irreversible situation to
\end{abstract}


press secretly the reflection of the lover about his departure. This strategy is the invention of the modern [wo]man which can appropriate the crisis. So, I defined the modern characteristic of this poem and proved that it is not a repeated expression of the traditional feeling of Koreans, but its de/reconstruction.

Key Words: Korean Modern Poetry; “Azaleas”; Kim Sowol; Reconstruction of the Tradition; Characteristics of Modern Poetry.

\section{한국 근대시의 문턱에서 발생한 사건: 김소월의 "진달래꽃"}

초록: 김소월은 한국 근대시의 문을 연 시인 중의 하나이다. 그의 시, “진달래꽃"은 오랫동안 한국시를 대표해왔고 한국 국민들에 의해 가장 많이 애송되어왔다. 그런데 이 시는 '한국적 정한'의 세계를 전형적으로 표현하고 있다고 이해되어 왔다. 이 논문에서 필자는 그러한 이해가 잘못된 이해임을 밝히고 한국적 정한을 주체적으로 극복하기 위한 모험의 시임을 논증한다. 이 논증은 이 시가 심정의 표현이 아니라 대화의 제기라는 텍스트 분석을 통해서 이루어졌으며, 이 논증과 더불어, “가시리”, “경기아리랑” 등 전통적인 시가와의 비교분석을 통해서 필자는 이 시가 전통적인 정서와 전통적인 형식을 계승하는 시가 아니라, 오히려 전통을 가져와 새로운 것으로 변용한 ‘근대시'임을 입증하였다.

주제어: 김소월; “진달래꽃"; 한국 최초의 근대시; 근대시의 특성; 전통의 계승과 극복.

\section{FENOMEN ZAISTNIALY U ZARANIA KOREAŃSKIEJ POEZJI WSPÓLCZESNEJ: „AZALIE” KIM SOWOLA}

Abstrakt: Kim Sowol jest jednym z tych koreańskich poetów, których uznaje się za prekursorów koreańskiej poezji współczesnej. Jego utwór "Azalie" (1925) jest uwielbianym przez Koreańczyków arcydziełem, porównywalnym z francuskim wierszem „Do Kassandry” Pierra de Ronsarda. Dotychczas podziwiano ten utwór jedynie w kategoriach ekspresywności sentymentalnej bez docenienia jego jakości dla poezji współczesnej Koreańczycy od dawien dawna wyrażali uczucia żalu i tęsknoty spowodowane rozłąką z ukochaną osobą. W utworze "Azalie" dostrzec można powtórzenie tych samych uczuć i okoliczności. Artykuł analizuje podejście oraz intencje podmiotu lirycznego jak i interpretuje na nowo jego motyw przewodni. Pozwoliło to na zaobserwowanie strategii ukrytych przekazów emocji osoby odchodzącej od podmiotu w obliczu nieuniknionej sytuacji rozstania. Strategią tą jest stworzenie współczesnej osoby (kobiety bądź mężczyzny), która może ów kryzys zażegnać. Autor definiuje zatem 
współczesny opis tego utworu i dowodzi, że nie jest to jedynie powtórzenie wyrażania tradycyjnych emocji Koreańczyków, lecz jego de- bądź rekonstrukcja.

Słowa kluczowe: Koreańska Poezja Współczesna; "Azalie”; Kim Sowol; Rekonstrukcja Tradycji; Opis Poezji Współczesnej.

\section{Misreadings around the first modern Korean poem, "Azaleas"}

This essay examines an event that occurred with the emergence of a singularity in the Korean world view at the dawn of modern Korean poetry. 'Modern Korean poetry' here refers to poems that have realized aesthetic achievements in a modern sense. As has been the case for most Third World literature, Korean literature was shaped amid a process of linguistic culture becoming reorganized along Western lines with the advent of Western modernity. This was a long process that followed a great many pathways. Yet the 'seed bed' of modernity within that process would have been planted with the emergence of many events and cultural factors that constituted the elements of modernity - and at some point there would have been the first emergence of cultural incidents and articles that could be viewed in their totality as 'modern'.

In my case, I view modern literature as having started at just such a moment. Defining the long process leading up that moment as representing the 'pre-modern', I attempt to examine the translation process between the pre-modern and modern. From that standpoint, modern Korean poetry first emerged in 1925. It was during that year that Kim Sowol published the poetry collection Azaleas 진달래꽃 (Maemunsa Press; 매문사), the poems of which are well suited to the definition of 'poetry' in the modern sense. The titular poem "Azaleas" has long been recited as a classic example of Korean poetry, achieving a maximum level of emotional density. The text of that poem reads as follows:

\footnotetext{
"When you leave, weary of me, without a word I shall gently let you go.
} 


\author{
From Mount Yak \\ in Yongbyon, \\ I shall gather armfuls of azaleas and scatter them on your way. \\ Step by step \\ on the flowers placed before you \\ tread lightly, softly as you go. \\ When you leave, \\ weary of me, \\ though I die, I'll not let one tear fall” (trans. Lee Peter 1990: 29)
}

Yet this poem has long languished under serious misreadings. While it is construed as representing a depiction of traditional Korean femininity, the resolute attitude of the (presumed to be) female speaker in the poem - her determination to "not shed a tear no matter what' when faced with abandonment by her love - seems to be clearly underscored, adding an element of the collective image of Korean womanhood in modern history: preserving her feminine submissiveness on the one hand, while fully bearing the world's adversities on the other.

This reading is closely tied to a perspective regarding Kim Sowol as an inheritor of Korea's traditional poetic forms. He is widely known to have been dubbed the "folk song poet" by his teacher Kim Ŏk (김억), when he first emerged on the scene in Joseon literature (개벽 Kaebyok, 1922: 146). This image of him as a 'preserver of tradition' spread far and wide; by the 1970s, the situation had reached the point where Kim Sowol's poems were being posited and analyzed as the most exemplary cases amid a wave of 'nationalistic perspective' in the 1970s, which sought to view the rhythms of modern Korean poetry as carrying on and expanding Korea's traditional meter.

It is also clearly recorded in Kim Ŏk's recollection in "The Unfortunate Poet Who Died Young", printed in 조선중앙일보 Joseon Joongangilbo in 1935, that Kim Sowol himself voiced displeasure with the 'folk song poet' sobriquet - a position that none of the interpreters have taken seriously. The poet's complaint was treated as little more than gossip. Yet if there is anything that can actually be said here and now, it is that his words contained truth. What truth? The truth that Kim Sowol was less an inheritor of traditional poetry than someone seeking to 'use' traditional themes, 
developing modern poetry within the context of the Korean Peninsula's linguistic culture.

\section{Key to new reading: look at the speaker's attitude}

By this, I mean something different from the claims - frequently made since the time of Kim Ŏk - that Kim was engaged in creative transformations of traditional poetry styles. Moreover, based on that fact, there is nothing at all resembling the arguments made during the age of 'national subject ideology' - namely that he succeeded in transforming traditional poetry forms into modern ones. Our position is that while Kim Sowol did make use of the traditional, he did so not as a continuation of tradition but as a break with it, executing a transition from the traditional to the modern in the process.

To understand this, the reader must first shed the persistent bad habit of isolating the final section of the poem and understanding the theme as a whole according to that section. The minimal units of poetry are individual poems, which must be read as wholes. Separating out one portion is possible only methodologically, and that approach is only valid when it serves in understanding the entire poem. When the general context is taken as a whole, we will be able to grasp what has been lacking in past analyses - and to proceed toward a new interpretation based on that understanding.

As mentioned previously, past analyzes of "Azaleas" have tended to focus on the poetic speaker's attitude: "No matter what, I'll not let one tear fall." To be sure, the interpreter is continually impressed by the sense of some quite persistent hesitation behind the expression of resoluteness. As a result, an interpretation is appended: that 'something else' exists behind that determined acceptance of fate, something that can be characterized in this way or that. What is astonishing is how the majority of interpreters have looked within that fearsome forbearance and seen lingering attachment and resentment. She may be forbearing outwardly, they conclude, but inwardly her emotions are roiling. When the external aspects are emphasized, the speaker's forbearance is presented as 'superhuman'; when the internal ones are underscored, a 'human being' is seen as existing within that superhuman exterior. This analysis is not a complex one, however. It 
does not open up and show any progress in the situation vis-à-vis the lover's departure. When we confer the label 'complex', it is not merely a matter of appearances being deceiving. The label is attached when we have grasped a structure beyond the simple surface, in which two conflicting aspects are juxtaposed, aspects that clash independently or artificially - to open up and reveal some new incident. Analyses that posit 'roiling agony within forbearance' make the latter as a disguise, or the former as 'emotion beyond healing'. Nothing changes as a result: there is no difference between the times before the poem is written (or read) and after it is written (read).

This simplicity of analysis is due mostly to the focus exclusively on the speaker's 'attitude' in the poem - a fixation that leads to the synecdochic fallacy, in which one effectively judges a poem as a whole in terms of one specific part. This poem contains not an 'attitude', but an action. We must first note that it is not an 'attitude' so much as an 'expression of attitude'. It is not the attitude that is presented as such; what is shown is the performative act of 'revealing'. Two versions of this revealing of attitude can be seen. First, there is the speaker expressing her relinquishing of action: "I shall gently let you go without a word". After that, there is the expression of a stance as an especially 'concentrated' action: "No matter what, I shall not shed a tear." The content is the same, yet the aspectual differences are considerable. What could this difference signify? To understand this, we must look at what has happened between these two expressions of attitude. Different actions take place in between. One is a "notice of action': the speaker will "pick [azaleas] by the armful" from Mt. Yak in Yeongbyeon and "strew [them] along the path you take." Next comes a demand for action from the listener: "With each step as you go / Tread lightly / Upon the flowers placed there." (Lee Peter 1990: 29).

What the reader should pay attention to in terms of this notice and demand is that neither is actually executed. Past analysts have interpreted the situation as having happened, basing their analyses on that reading: the speaker 'I' has already strewn the azaleas, and the lover has departed, "tread[ing] lightly" over the flowers on his way. Yet the incident has not actually happened yet in the poem; the possibility of the incident has merely been raised. One other thing of which we should be wary is the possible lack of conformity between words and meaning. Literary language in particular, as Roland Barthes (1964/1993: 1354) established long ago, is fundamentally an act of 
"denegation". The idea of literature being 'a lie' (or a trick) is a reference to this. In the poem, the speaker has merely said that she intends to strew the azaleas; she has not actually done so. Her message could be a literal announcement of the action that she plans to take. Conversely, it could also be a form of blackmail. In any case, her notice creates a hypothetical situation in which she is strewing azaleas along her lover's path as he takes his leave. Why should this imaginary scenario be necessary? To elicit a reaction from the other party. The 'demand for action' that follows is thus closely linked to this 'notice'.

\section{Speaker's hidden intention under the sweet expression}

Let us look more closely at the imaginary scenario. Perhaps the two of them share the memory of frolicking merrily and picking azaleas on Mt. Yak in Yeongbyeon. Each individual azalea petal is now part of a happy past memory. The speaker is acutely aware that she cannot stop her love from leaving - yet she cannot simply do nothing. To the shards of memory, she must ascribe some other role than to pierce her heart. If the memories were happy in nature, it must not have been so for the speaker alone, but for the lover as well. Let us suppose the speaker does strew them before her parting lover's feet, telling him to tread on them as he goes. He may tread "lightly" over them, having relinquished all feeling for the speaker. But those petals carry within them the past moments between her and the lover. For him to step heedlessly over them would be the act of a person who once felt love now 'tramping' (not 'treading lightly': according to professor Lee Kimoon (1998: 174), who hails from the same province as the poet, the word jeuryeobapda (즈려밟다) in the poem is a variant of jirebapda (지레밟다) or jiribapda (지리밟다), meaning 'to step forcefully upon something ${ }^{1}$ ') over something that reflects his wholeness and has become synonymous with his humanity, and furthermore an act of

${ }^{1}$ It might be why McCann has translated this passage as "press deep, step lightly, and go" (McCann 2007: 153). But in my opinion this translation exposes immediately the hidden intention of poet, and so is inappropriate. 
trampling on happiness as his own 'property'. The faster the lover seeks to disappear, the more he destroys both the speaker and himself.

This, of course, is how the speaker views it. But she uses this idea to provoke her love, urging him to 'tread upon' it as he goes. The reader has no way of knowing the lover's thoughts. If he is someone who once shared love with the speaker, however, we may presume that he 'deserves' her. By 'deserve', I mean that he is someone who would have to acknowledge the speaker's thoughts and reflect once more on his departure when faced with that circumstance.

Thus begins a game of psychological tug-of-war between the speaker and her lover. The landscapes in the second and third stanzas of "Azaleas" see the field being opened for this psychological combat. The attitude as 'concentrated action' in the fourth stanza may be more appropriately read as another strategy devised to turn the psychological warfare in the speaker's favor. She speaks, telling her love to tread on the petals as he goes - 'lightly' and thus 'trampling', for in this context the two words are synonymous. She goes on to speak more forcefully, urging him to tread on the flowers, as she will "not let one tear fall". In my opinion and in my suggested translation, the poet's attitude can be read as:

\footnotetext{
"I will hold back the tears that I should be shedding, she says; that amount of sadness will not be reduced, but will build up in my heart, leading those azalea petals to fester as your "possession" of happiness. I shall not shed a tear, so tread upon them as go. No matter what. No matter what, I shall not shed a tear."
}

If the departing lover truly is right for her, he will be plunged into a dilemma - and the reader will sense a wave of tremendous feeling from this poem, surging unpredictably as if from the open sea. The poem can thus be seen as both a dialogue - a skillful battle between the speaker and her lover - and as the sound box for an appeal to the reader to take part in that battle. The reader becomes drawn into the startling modern landscape developed by a Joseon-era poet in the early 20th century.

Does it even need explaining that this landscape is an exceedingly modern one? Unfortunately, it might. Let us state it in concise terms. Modernity is a spatial and temporal way of being in which humanity has assumed agency in the world (this does not refer to any specific era in history - or rather, it was an era, but one that has 
come to transcend historicity with the passage of time), and the substantive unit of that humanity is the individual. An individual here is a single intelligent life form, and the idea of such an individual being the substantive unit of the era of humanity signifies some break with the community as a precondition for individuality.

\section{Modern singularity of "Azaleas" in comparison with the traditional poems}

Viewing "Azaleas" in terms of this abbreviated blueprint, we note first and foremost that the agent behind the poem's drama is the speaker 'I'. The subject in the poem is not Koreans' collective conception of womanhood, nor does she represent some universal idea of acquiescence to destiny. Such a general entity would not be capable of making this complex wager. Next, one reading of the speaker's bet will be naturally led to assess its intertextual relatedness within the context of Korean linguistic culture - for the theme of expressing affection and resentment toward a parting lover is a very familiar one to us. Similar stories abound in everything from "Gasiri" 가시리 (Are You Going?), a folk song dating all the way back to the Goryeo era (928-1392), and the "Arirang" 아리랑 songs that flourished from the mid-19th century to the various popular songs of today. Yet the attitude is a different one-a difference that we can grasp by comparing "Azaleas" with "Gasiri" and "Gyeonggi Arirang" 경기아리랑.

The following is the full text of "Gasiri":

\footnotetext{
"Are you going away, going away? Are you leaving me and going away?

How shall I live? Are you leaving me and going away?

I would like to hold you back, but I fear you might not return

I sadly let you go, so please return just as you go."

(Yoon, Seonghyun 2007: 90-91, translation by Jeong Myeong Kyo)
}

The core theme of "Gasiri" is well established to lie in the "please return just as you go" line. The poem displays the wondrous magic of love. The sadness of a goodbye arises at the moment of "as you go" and the sadness is amplified during the departure. Yet at the 
moment of "please return", the sadness transforms into delight. Not only that, but the event of "returning just as you go" amplifies the delight as much as it amplified the sadness. The incident of parting is a medium that intensifies the love - just as the pain of eating spicy food causes us to secrete the endorphins that make us love spicy food. But the methodological mechanism of the parting is rooted in the belief that the lover will never return. In other words, the poem is unaware of a 'separation'-and that aspect signifies that the poem lies on the far side of modernity, for modernity starts from such a separation. Why? Because only through the existence of such a separation can an 'I' be formed - the 'I' as 'individual', a core unit of modernity.

It is for this reason that waves of romanticism surged at the outset of modernity, across all times and places. According to Goldman, the romantic worldview is one of fundamental disharmony with the world, something he spoke of simply as 'rien' - 'nothing'. That rien denotes the absence of a world of wholeness to be trusted in and relied upon. It is the world referred to by Lukács in the first sentence of his Theory of the Novel, the world in which the stars in the night sky illuminated paths for us to follow. That world has disappeared - hence, 'nothing'. But Goldman omitted one thing. For that world of wholeness did not merely collapse. As it crumbled, a new entity sprang from it like an electron: the 'individual'. If we keep this in mind, the romantic world view should be characterized not as 'nothing', but as 'nothing and I' (cf. Jeong Myeong Kyo 2006: 63-64).

Amid the onslaught of the products of modernity, people on the Korean Peninsula also began to experience this separation. This feeling of rupture is expressed in different ways through the lyrics of the "Arirang" songs, which are known to have been sung "as popular folk songs reaching the Seoul and Gyeonggi regions in the mid- and late 19th century" (Jeong Woo-taek 2012: 157). The "Gyeonggi Arirang", which is one of the most widely sung by South Koreans, expresses a reaction to that rupture as follows:

Arirang arirang arariyo

Crossing over Arirang Pass

My love who goes, leaving me behind 
Shall not go ten li before his feet are sore ${ }^{2}$

The crucial difference between these lyrics and those of "Gasiri" is that the certainty of the departing lover's return has been removed. The absence of that belief means that the avenue of psychological exchange between the speaker and the lover is closed; the speaker and the lover no longer possess the same spiritual pillar, the same material basis. To paraphrase Sartre (1947: 93) hell is now other people ("l'enfer, c'est les Autres" in "Huis clos"). Resigning herself to the truth of that break, the speaker in "Gyeonggi Arirang" unleashes a curse, driven by an impulse to make the lover return by force if necessary. As an emotional response, this is quite coarse immediate, peripheral, simple. It is a feeling that anyone might experience at the start of an unwanted farewell. But the speaker's role is absent here. The speaker has become an independent entity through her separation from the lover, but she has not yet become a subjective agent. She seeks to punish the lover, drawing on an 'other' in the form of soreness - as though through that soreness, the lover might return and seek atonement.

By comparing these two works, we can immediately see who the speaker in "Azaleas" is: someone who accepts separation as her circumstance, and at the same seeks to impose her own actions to overcome that separation. In other words, she is someone who possesses both independence as an 'I' and the 'ability to act'. Such an individual is a 'modern person' in the true sense. The 'I' as independent being sees herself as separate from the other beings around her, from the community to which she belongs. At the same time, the 'I' as 'actant' introduces her own spirit and labor to create a society in which people transcend that separateness to live together. Yet if she is a modern person with an accurate understanding of the duality of 'separateness' and 'activity', she will understand that her

\footnotetext{
2 This folk song is one amid the several types of 'Arirang' songs (which have been registered as 'Intangible Cultural Heritage' by UNESCO, in December 2012 [of South Korea] and 2014 [of North Korea]) and has been classified as the basic version of the various Gyeonggi Arirang Song versions. This version is globally spread through all the Korean people and has been designated as an 'official anthem of the unified Korean Team in International Sport Game' in accordance with the agreement between South Korea and North Korea in the 'Meeting for Sports', Feb. 12, 1991. There are diverse unauthorized translations of this folk song (Gyeonggi Arirang). The translation in this article is personal on reference to several examples.
} 
actions cannot overcome the separation in a single effort. The battle will be a long and arduous one. She will have to rack her brain and open her heart. She will have to deceive and plead. It is for that reason that the speaker in "Azaleas" announces her intent to erect an imaginary stage before her departing lover, which she will use in her psychological combat with him. The poet was certainly well aware of how very familiar Koreans were with this sort of parting situation.

\section{Modern poetry as transformation of the traditional emotion}

The situation of investing such concentrated emotions in 'parting' is a very Korean emotional circumstance; in Western literature, matters of love typically manifested in the form of adultery (cf. Micha 1976: 70). Within his unconsciousness, he would have also had an intuitive grasp of the evolution in Koreans' response to this situation. Meeting the demands of emotional affinity with the reader by re-introducing a traditional situation, he then proceeds to abandon the traditional response and create a new one. The result is "Azaleas" - a perfect poem.

In using the creation of an exquisite 'wager' to triumph over the feelings of lingering attachment that South Koreans fall prey to so often even today, "Azaleas" forged the attitude of an individual with agency, someone who would direct her own situation of parting. This moment marked the birth of Koreans as modern individuals - for the first time, "adventurers and creators of the world" (Apollinaire 1918: 394). 


\section{Bibliography}

Apollinaire, Guillaume. 1918. L'Esprit nouveau et les Poètes(1917), Mercure de France, vol. 130, no. 491 (December, 1): 385-96

Barthes, Roland. 1964/1993. Deux Critiques. In Essais Critiques (1964), Euvres Complètes - Tome 1 : 1942-1965, pp. 13521356. Paris: Éditions du Seuil.

Jeong, Woo-taek. 2012. Modern Poetry and the Arirang. [in:] Arirang Festival - The publishing book of the Symposium, Arirang in Cultures, Arirang in the World, co-arranged by The Korean Ministry of Culture and The International Association of Comparative Korean Studies at The Korean National Museum, Seoul, June 15. 2012.

Jeong, Myeong Kyo (정명교). 2006. 한국 현대시에서 서정성의 확대가 일어나기까지 Hangug hyeondaesi-eseo seojeongseong-ui hwagdae-ga ironagi-ggaji (Before the Expansion of Lyricism in Modern Korean Poetry). 한국시학연구 Hangug si-hag yeongu (Korean Poetics Studies), No. 16 (2006):49-80.

Kim, Ŏk (김억). 1923. 시단 의 일년 Sidan-ui Illyeon (The Year in Poetry). 개벽 開閣 Kaebyok [monthly] 42 (December).

Kim, Ŏk (김억). 1935. The Unfortunate Poet Who Died Young. Joseon Joongangilbo. January 22-26.

Kim, Sowol (김소월). 1922. 진달래꽃 Jindallae-ggot (Azaleas), 개벽 開䦕 Kaebyok [monthly] $25^{\text {th }}$ July.

Kim, Sowol. 2007 Azaleas, transl. by David McCann. New York : Columbia University Press.

Kim, Sowol. transl. by Jaihiun J. Kim \& Ronald B. Hatch. 1998. Fugitive Dreams: Poems by Sowŏl Kim. Vancouver: Ronsdale Press.

Lee, Peter H. (ed). 1990. Modern Korean Literature. Honolulu: University of Hawaii Press.

Lee, Ki-moon. 1995. On Language in the Poetry of Kim Sowol. In Kim Sowol. The Modern Interpretation of Korean Literature. ed. Kim, Hakdong. pp. 165-192. Seoul: The Sogang University Press.

Lukács, Georg. 1971. The Theory of the Novel. A Historicophilosophical Essay on the Forms of Great Epic Literature. Trans. Anna Bostock. Cambridge, Massachusetts: MIT Press: 
Myeong Kyo JEONG: An Event at The Dawn of Modern Korean...

Micha, Alexandre. 1976. De la chanson de geste au roman. Genève: Droz.

Sartre, Jean-Paul. 1947. Huis clos suivi de Les mouches. Paris: Gallimard

Yoon, Seonghyun. 2007. The Beauty of Popular Songs de Goryeo. Seoul: Taehaksa 